\title{
Clinical and hormonal profile of patients diagnosed with polycystic ovarian syndrome at tertiary care hospital in Tamil Nadu
}

\author{
Sathiya S, Renuka S.*, Famida A. M., Jennifer Britto J., Vijayalakshmi K., Sailatha R.
}

Department of Obstetrics and Gynaecology, Chettinad Hospital and Research Institute, Kelambakkam, Kanchipuram, Tamil Nadu, India

Received: 03 July 2019

Accepted: 14 August 2019

\author{
*Correspondence: \\ Dr. Renuka S., \\ E-mail: dralgates@gmail.com
}

Copyright: (c) the author(s), publisher and licensee Medip Academy. This is an open-access article distributed under the terms of the Creative Commons Attribution Non-Commercial License, which permits unrestricted non-commercial use, distribution, and reproduction in any medium, provided the original work is properly cited.

\section{ABSTRACT}

Background: In recent years due to the changing sedentary life style, irregular periods and infertility has become a major concern. There are many causes for infertility out of which ovulatory disorders contribute to a great extend. The main objective of the study was to assess the clinical and hormonal profile of patients diagnosed with polycystic ovarian disease at tertiary care hospital in Tamil Nadu.

Methods: This study was a cross sectional study and was carried out at the Department of Obstetrics and Gynaecology at a tertiary care hospital of Tamil Nadu. The study was done for a period of 6 months. For confirming polycystic ovaries, patients were interviewed thoroughly about their menstrual and fertility history. Blood investigations like LH, FSH were done on D2/D3 of menstrual cycle. 125 patients with PCOS were included in this study. The data was analysed with SPSS-IBM (V.22.0) software.

Results: The patients having polycystic ovaries were higher in women of 21-30 years of age. BMI was more than 25. Infertility was found that $57 \%$, hirsutism $45 \%$, oligomenorrhoea $21 \%$ and amenorrhea $20 \%$. On day 2 , mean serum

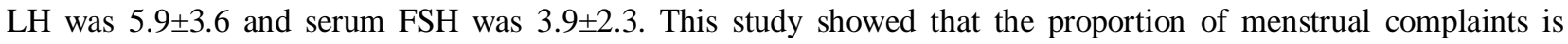
reported more in higher age group. Likewise lower income group presented with menstrual complaints. This was found to be statistically significant ( $\mathrm{P}$ value $<0.05$ ).

Conclusions: The study showed that patients diagnosed to have PCOS overweight. PCO in obese women had more severe ovulatory dysfunction. Infertility was the most common complaint.

Keywords: Hormones, Obesity, PCO, Usg

\section{INTRODUCTION}

Polycystic ovarian syndrome was first described by Stein and Leventhal in $1935 .{ }^{1}$ Polycystic ovarian syndrome is a disorder of heterogeneous androgen excess with varying degrees of metabolic and reproductive abnormalities. This is greatly influenced by multiple genetic and environmental factors. Its clinical manifestations may include menstrual irregularities, signs of excessive androgens, and obesity. Elevated serum LH levels is a common feature of PCOS. ${ }^{2}$ The National Institute for Health (NIH) criteria 1990 was revised and Rotterdam's criteria is followed worldwide from 2003. ${ }^{3}$ Polycystic ovarian syndrome is one of the most common endocrinological disorder in reproductive age group affecting about $6-8 \%$ of women with a broad spectrum of clinical manifestations. ${ }^{4-6}$ Globally, estimation of prevalence of polycystic ovarian syndrome are highly variable ranging between 2.2 to as high as $26 \% .^{7-9}$ Various manifestations of polycystic ovaries usually start 
from the time of menarche. Many of these features usually are in the evolutionary stage during the transitional phase of puberty which in later phase stabilizes and established. The 2003 Rotterdam ESHRE/ASRM - sponsored PCOS consensus workshop concluded that PCOS is a syndrome of ovarian dysfunction along with cardinal features of hyper androgenism and polycystic ovarian morphology. ${ }^{10,11}$

Using Rotterdam criteria, community based studies among reproductive age group has showed different prevalance values ranging from $2 \%-7.5 \%$ in China and $6.3 \%$ in Srilanka. ${ }^{12-14}$ Using NIH criteria reported PCOS in the range of $5-8 \%{ }^{15}$

There are very few Indian studies on PCOS, most of them done in schools and hospital setups in view of easy accessibility. These studies revealed the prevalence rate of PCOS as ranging from $9.13-36 \% .^{16,17}$

The objective of the study was to access the clinical and hormonal profile of the patients diagnosed with PCOS at tertiary care hospitals in Tamil Nadu.

\section{METHODS}

The study was observational prospective study which was carried out in the department of gynaecology for a period of 6 months from Jan 2018 - Jun 2018 at Chettinad Hospital and Research Institute, Kelambakkam, Kanchipuram, Tamil Nadu. The study population included both married and unmarried women of 15-40 years of age. For participants less than 18 years of age, parentral consent was obtained. Girls aged 15-17 years who have attained menarchy atleast 3 years before were enrolled in the study. PCOS women who were included in the study were defined by using two out of the three diagnostic parameters of Rotterdam criteria (i) oligomenorrhoea/anovulation (ii) Hyperandrogenism (a) clinical hirsitusim of less commonly male pattern alopecia or (b) Biochemical (raised free testosterone) (iii) Polycystic ovaries on ultrasound. Exclusion criteria included pregnant women, women who take medications like OCPs and steroids, chronic illness such as diabetes mellitus, congenital adrenal hyperplasia, hyperprolactinemia, hepatic or renal disease.

The patients were enrolled into the study based on the inclusion and exclusion criteria. Informed and written consent was obtained from all the patients enrolled in this study. All the enrolled patients were asked for detailed history about their menstural cycle, which included the cycle regularity, intermenstural bleeding interval and days of bleeding. Other histories like type of family (Nuclear or joint), type of habitat (rural or Urban) was also obtained. Blood investigation for hormonal analysis like blood glucose, LH, FHS, LHS:FHS ratio, was done on either the second or third day of menstural cycle. Clinical hyperandrogenism was determined by clinical features of hirsitusism assessed by Ferriman - Gallway score of more than or equal to 8 over 9 body parts. ${ }^{18}$ Ferriman Gallaway Score (FGS) was used for categorizing hirsutism. Score 11-20 (Grade I), Score 2130 (Grade II), Score 31-40 (Grade III) and Score $>40$ (Grade IV). Score $<11 \rightarrow$ Normal.

Body mass index was calculated on the basis of WHOAsian Indian Classification of BMI as below. ${ }^{19-21}$ Under weight; BMI less than $17.9 \mathrm{~kg} / \mathrm{m}^{2}$, Normal: BMI equal to 18-22.9 kg/m², Overweight: BMI more than $23 \mathrm{~kg} / \mathrm{m}^{2}$, Obese: BMI more than $25 \mathrm{~kg} / \mathrm{m}^{2}$. Ultrasound diagnosis was based on the presence of antral follicles less than 12 in number and size less than $10 \mathrm{~mm}$ in either one or both the ovaries. 22

\section{Sample size determination}

For calculation of sample size, the formula used is,

$$
n=\frac{Z^{2} \mathrm{x}(\mathrm{p}) \times(1-\mathrm{p})}{L^{2}}
$$

where, $\mathrm{n}$ is the sample size, $\mathrm{Z}$ is the normal deviate at a level of significance ( $Z$ is 1.96 for $5 \%$ level of significance), $\mathrm{L}$ is the relative error, which is taken as $5 \%$ $\mathrm{P}$ is the proportion of the population with the disease under study i.e, prevalence of PCOD in India ranges from $9-26 \%$ in reproductive age group women. With prevalence of PCOD in a study done in south India* was at $9 \%$.

$$
n=\frac{(1.96)^{2} \times(0.09) \times(0.91)}{(0.05)^{2}}=\frac{3146}{25}=125
$$

$\mathrm{n}=125$ was the calculated sample size and 125 study participants were recruited in the study.

\section{Statistical analysis}

Data was analysed with statistical package for social sciences (SPSS-IBM) version 22.0. Proportions and means were calculated. Tests of significance were applied after assessing the normality of data. Chi square test was applied. $\mathrm{P}$ value $<0.05$ was considered significant.

\section{RESULTS}

\section{Baseline characteristics of study participants}

A total of $125(100 \%)$ study participants were included in the study. The age of the study participants ranged between 15 years to 40 years. The mean \pm SD age of study participants was $28.54 \pm 5.95$. Majority belongs to urban area $91(72.8 \%)$ (Table 1$)$.

\section{Medical history}

Among the study participants, menstural complaints were the presenting symptoms in $54(43.2 \%)$ of study 
participants. Around ninety one percent had these menstural complaints less than a year period. $74(59.2 \%)$ study participants had history of other medical disorders (Table 2).

Table 1: Baseline parameters of study participants $(n=125)$.

\begin{tabular}{|c|c|}
\hline Profile of study participants & $\mathbf{N}=125, \mathbf{N}(\%)$ \\
\hline \multicolumn{2}{|l|}{ Age group } \\
\hline $15-20$ years & $3(2.4)$ \\
\hline $21-25$ years & $46(36.8)$ \\
\hline $26-30$ years & $56(44.8)$ \\
\hline $31-40$ years & $20(16)$ \\
\hline \multicolumn{2}{|l|}{ Residence } \\
\hline Urban & $91(72.8)$ \\
\hline Rural & $34(27.2)$ \\
\hline \multicolumn{2}{|l|}{ Education } \\
\hline Primary & $11(8.8)$ \\
\hline High School & $58(46.4)$ \\
\hline Graduate & $42(33.6)$ \\
\hline Post graduate & $8(11.4)$ \\
\hline \multicolumn{2}{|l|}{ Occupation } \\
\hline Daily wages & $14(11.2)$ \\
\hline Self employed & $13(10.4)$ \\
\hline Professional & $40(32)$ \\
\hline Housewife & $58(46.4)$ \\
\hline \multicolumn{2}{|l|}{ Socio economic class } \\
\hline I & $6(4.8)$ \\
\hline II & $37(29.6)$ \\
\hline III & $59(47.2)$ \\
\hline IV & $21(16.8)$ \\
\hline $\mathrm{V}$ & $2(1.6)$ \\
\hline \multicolumn{2}{|c|}{ Total family income per month (in rupees) } \\
\hline$\leq 5000$ & $12(9.6)$ \\
\hline $5001-10000$ & $43(34.4)$ \\
\hline $10001-20000$ & $24(19.2)$ \\
\hline$>20000$ & $46(36.8)$ \\
\hline \multicolumn{2}{|l|}{ Type of family } \\
\hline Nuclear & $80(64)$ \\
\hline Joint & $45(36)$ \\
\hline \multicolumn{2}{|l|}{ Hirsutism } \\
\hline FG Score $>40$ & 1.6 \\
\hline FG Score $31-40$ & 33 \\
\hline FG Score 21- 30 & 34 \\
\hline FG Score 11- 20 & 54 \\
\hline
\end{tabular}

\section{Vital parameters and anthropometry}

Vital parameters and anthropometric findings of participants are shown in the Table 3.

\section{Hormonal and other blood parameters}

Median value of LH, FSH, Prolactin, TSH, hemoglobin and RBS of participants was 5.41, 3.42, 10, 2.4, 10.5 and 92 respectively (Table 4 ).

\section{LH/FSH ratio and Ultrasound findings}

Mean (SD) LH/FSH ratio of study participants was 1.6 $( \pm 0.748)$ with a median value of 1.497 (minimum to maximum: 0.22 to 5.6). Ultrasound findings were suggestive of PCOD in 91 (72.8\%) of study participants. Rotterdam criteria was fulfilled with $84(67.2 \%)$ of study participants.

Table 2: Distribution of study participants according to medical history $(n=125)$.

\begin{tabular}{|c|c|}
\hline Medical history & $\mathbf{N}=125 \mathrm{~N}(\%)$ \\
\hline \multicolumn{2}{|l|}{ Age at menarche } \\
\hline $10-15$ years & $121(96.8)$ \\
\hline $16-20$ years & $4(3.2)$ \\
\hline \multicolumn{2}{|l|}{ Duration of marriage } \\
\hline$<1$ year & $8(6.4)$ \\
\hline $1-5$ years & $72(57.6)$ \\
\hline$>5$ years & $45(36)$ \\
\hline \multicolumn{2}{|l|}{ Medical disorders* } \\
\hline Hypothyroidism & $27(21.6)$ \\
\hline Diabetes mellitus & $15(12)$ \\
\hline Hypertension & $11(8.8)$ \\
\hline None & $51(40.8)$ \\
\hline \multicolumn{2}{|c|}{ Presenting complaints* } \\
\hline Oligomenorrhea & $21(16.8)$ \\
\hline Menorrhagia & $13(10.4)$ \\
\hline Amenorrhea & $20(16)$ \\
\hline Primary infertility & $57(45.6)$ \\
\hline Secondary infertility & $14(11.2)$ \\
\hline Hirsutism & $45(36)$ \\
\hline Acne & $8(6.4)$ \\
\hline \multicolumn{2}{|c|}{ Duration of menstural complaints $(n=54)$} \\
\hline$<1$ year & $49(90.7)$ \\
\hline $1-2$ years & $3(5.6)$ \\
\hline$>2$ years & $2(3.7)$ \\
\hline \multicolumn{2}{|c|}{ Days of menstural cycle } \\
\hline $0-10$ days & $5(4)$ \\
\hline 11-20 days & $55(44)$ \\
\hline 21-30 days & $51(40.8)$ \\
\hline 31-45 days & $5(4)$ \\
\hline$>45$ days & $9(7.2)$ \\
\hline \multicolumn{2}{|l|}{ BMI classification** } \\
\hline$<18.5$ & $28(18.3)$ \\
\hline $18.5-22.9$ & $32(20.9)$ \\
\hline $23-24.9$ & $29(19)$ \\
\hline$>25$ & $64(41.8)$ \\
\hline
\end{tabular}

$\mathrm{Bi}$ variate analysis was done to find any association between menstural and other complaints with selected variables such as age group, residence, socioeconomic status, family income and BMI classification and $\mathrm{LH}$, FSH and prolaction levels. It was found that the proportion of other complaints was more in lower age 
group and menstural complaints are reported more in higher age group.

Table 3: Vital parameters of study participants $(n=125)$.

\begin{tabular}{|l|l|}
\hline $\begin{array}{l}\text { Vital parameters and } \\
\text { anthropometry }\end{array}$ & Mean \pm SD \\
\hline Heart rate (per min) & $71 \pm 19$ \\
\hline Respiratory rate (per min) & $16 \pm 8$ \\
\hline Temperature (F) & $98.5 \pm 1.1$ \\
\hline Height (in cm) & $157 \pm 6.6$ \\
\hline Weight (in kg) & $64 \pm 11$ \\
\hline BMI $\left(\mathrm{kg} / \mathrm{m}^{2}\right)$ & $25.6 \pm 3.7$ \\
\hline $\begin{array}{l}\text { Mean Ferriman Gallaway Score } \\
(\text { FGS })\end{array}$ & $18.7 \pm 4.32$ \\
\hline
\end{tabular}

Likewise, higher income group presenting with other complaints were more and lower income group presented

with menstural complaints. This was found to be statistically significant ( $\mathrm{p}$ value $<0.05$ ). However, there was no significant difference among different complaints with respect to hormonal levels.

Table 4: Hormonal and other blood parameters of study participants $(\mathrm{n}=125)$.

\begin{tabular}{|llll|}
\hline $\begin{array}{l}\text { Blood } \\
\text { parameters }\end{array}$ & Mean \pm SD & Minimum & Maximum \\
\hline LH & $5.9 \pm 3.6$ & 1.2 & 21.84 \\
\hline FSH & $3.9 \pm 2.3$ & 1.10 & 16.57 \\
\hline Prolactin & $9.5 \pm 4.2$ & 2.10 & 22.36 \\
\hline TSH (IU/ml) & $3.2 \pm 3.6$ & 0.93 & 20.40 \\
\hline $\begin{array}{l}\text { Hemoglobin } \\
\text { (gm/dl) }\end{array}$ & $10.4 \pm 2.0$ & 6.8 & 13.6 \\
\hline $\begin{array}{l}\text { Serum random } \\
\text { blood sugar } \\
\text { (gm/dl) }\end{array}$ & $92 \pm 8$ & 1.13 & 203 \\
\hline
\end{tabular}

Table 5: Association between presenting complaints and selected variables $(n=125)$.

\begin{tabular}{|c|c|c|c|}
\hline Profile of study participants & $\begin{array}{l}\text { Only menstrual complaints } \mathbf{n}=\mathbf{5 4} \\
\mathrm{N}(\%)\end{array}$ & $\begin{array}{l}\text { Other complaints } * \mathbf{n}=\mathbf{7 1} \\
\mathbf{N}(\%)\end{array}$ & p value \\
\hline \multicolumn{4}{|l|}{ Age group } \\
\hline $15-20$ years & $2(3.7)$ & $1(1.4)$ & \multirow{4}{*}{0.005} \\
\hline $21-25$ years & $20(37)$ & $26(36.6)$ & \\
\hline $26-30$ years & $17(31.5)$ & $39(54.9)$ & \\
\hline $31-40$ years & $15(27.8)$ & $5(7)$ & \\
\hline \multicolumn{3}{|l|}{ Residence } & \multirow{3}{*}{0.780} \\
\hline Urban & $40(74.1)$ & $51(71.8)$ & \\
\hline Rural & $14(25.9)$ & $20(28.2)$ & \\
\hline \multicolumn{3}{|l|}{ Socio economic class } & \multirow{6}{*}{0.237} \\
\hline I & $2(3.7)$ & $4(5.6)$ & \\
\hline II & $13(24.1)$ & $24(33.8)$ & \\
\hline III & $25(46.3)$ & $34(47.9)$ & \\
\hline IV & $12(22.2)$ & $9(12.7)$ & \\
\hline V & $2(3.7)$ & 0 & \\
\hline \multicolumn{3}{|c|}{ Total family income per month (in rupees) } & \multirow{5}{*}{0.005} \\
\hline$\leq 5000$ & $11(20.3)$ & $1(1.4)$ & \\
\hline $5001-10000$ & $16(29.6)$ & $27(38)$ & \\
\hline $10001-20000$ & $10(18.5)$ & $14(19.7)$ & \\
\hline$>20000$ & $17(31.5)$ & $29(40.8)$ & \\
\hline \multicolumn{3}{|l|}{ BMI classification } & \multirow{5}{*}{0.975} \\
\hline$<18.5$ & $8(14.8)$ & $20(28.1)$ & \\
\hline $18.5-22.9$ & $10(18.5)$ & $22(30.9)$ & \\
\hline $23-24.9$ & $12(22.2)$ & $17(23.9)$ & \\
\hline$>25$ & $24(44.4)$ & $12(16.9)$ & \\
\hline \multicolumn{3}{|l|}{ LH levels (Day 2) } & \multirow{3}{*}{0.519} \\
\hline$\leq 5.41$ & $29(53.7)$ & $34(47.9)$ & \\
\hline$>5.42$ & $25(46.3)$ & $37(52.1)$ & \\
\hline \multicolumn{3}{|l|}{ FSH levels (Day 2) } & \multirow{3}{*}{0.08} \\
\hline$\leq 3.42$ & $32(59.3)$ & $31(43.7)$ & \\
\hline$>3.42$ & $22(40.7)$ & $40(56.3)$ & \\
\hline \multicolumn{3}{|l|}{ Prolactin levels (Day 2) } & \multirow{3}{*}{0.008} \\
\hline$\leq 10$ & $37(80.4)$ & $31(55.4)$ & \\
\hline$>10$ & $9(19.6)$ & $25(44.6)$ & \\
\hline
\end{tabular}

Chi square test applied, p value $>0.05$ is significant, *Infertility,acne and hirsutism etc., 


\section{DISCUSSION}

PCOS is one of the most important causes for irregular menstural cycle. In a study conducted by Balen et al, ammenhorea was present in $19.2 \%$ of patients as compared to $16 \%$ in our patients. ${ }^{22}$ Other clinical features include hirsutism, infertility and obesity. Obesity or increased BMI and increasing age of marriage can also be attributing to cause infertility. Hence these women should be taught a healthier life style. The importance of regular physical activity and having their BMI less than helps in correction of the menstural irregularities and increasing the success rate of treating infertility patients. ${ }^{23}$ Optimal time for family initiation should also be taught. ${ }^{23}$ It is found that there is significant decline in infertility with increasing BMI and age. ${ }^{24}$ Role of combined oral contraceptive pills in achieving regular menstural cycles is advised. Prevalance of PCOS is found to be more in younger age group ( $<35$ years of age) than prevalence in older women. The attributing cause to this prevalence could be the physiological decline of the follicles thereby leading to a normal ovarian feature in the ultrasound. Our study showed that the mean age of the patients was $28.5 \pm 5.95$ and a majority $44.8 \%$ belonged to age group between 26-30 years. Muralidhara et al in KMC, Mangalore did a study in 2012, where the mean age among patients with PCOS was $27 \pm 7.1$ which is comparable to our study. ${ }^{25}$ In a study done by Spandane et al in 2017, the mean age among PCOS patients was $27 \pm 5$ which is comparable to the study. ${ }^{26}$ In the present study, most of the PCOS patients lived in the urban area $72.8 \%$ and in rural area $34 \%$. In a study done by Radha et al in $2016,88 \%$ of the PCOS patients lived in the urban area which is comparable to present study. ${ }^{27}$ The prevalence of PCOS in infertile women in the study is $45.6 \%$ and this is comparable to $40 \%$ of infertility in PCOS women in a study conducted by Couzin. ${ }^{28}$ In the study, androgenic features like acene in the PCOS patients was $8 \%$ which is comparable to a study conducted by Nandrelle $\mathrm{K}$ et al where acne was present in $9.2 \% .{ }^{29}$ Even small degrees of weight loss like $1-3 \mathrm{kgs}$, may help in restoring and regularizing menstural cycle and ovulation. ${ }^{30}$ It is important to be aware that around $75 \%$ of lean body women with polycystic ovaries will have insulin resistance and about $50 \%$ will have metabolic syndromes. In the study, the mean FG Score was $18.7 \pm 4.32$ which is comparable to a study conducted by Atallah et al where the mean FG Score in PCOS was 20.1 \pm 7.8 . $^{31}$ The mean $\mathrm{LH}$ value in the study is $5.9 \mathrm{IU} / \mathrm{L}$ which is comparable to a study done by Shanmugam et al where the mean LH value is 5.6 IU/L. ${ }^{32}$ The incidence of cardiometabolic risk factors increase in women with polycystic ovarian syndrome. ${ }^{33}$

\section{CONCLUSION}

The study showed that most of the PCOS patients were obese and hirsutism was present in almost majority of the patients. The most common presenting complaints in PCOS patients was primary Infertility and second most common presenting complaint being oligomennorhoea. The study concludes that significant number of PCOS patients are obese and present with menstrual and infertility complaints. PCOS in obese women have more severe ovulatory dysfunction. It was found that the proportion of complaints like hirusitism and acne was more in lower age group and menstural complaints are significant in higher age group. Likewise, higher income group presented with other complaints and lower income group presented with menstural complaints. This was found to be statistically significant ( $\mathrm{P}$ value $<0.05)$. However, there was no significant difference found among different complaints with respect to hormonal levels. The significant number of patients in the study live in the urban area with nuclear type of family. Hence obese women with PCOS is one of the major cause for the infertility and it needs social awareness right from the school level.

\section{Funding: No funding sources}

Conflict of interest: None declared

Ethical approval: The study was approved by the Institutional Ethics Committee

\section{REFERENCES}

1. Azziz R, Marin C, Hoq L, Badamgarav E, Song P. Health care-related economic burden of the polycystic ovary syndrome during the reproductive life span. J Clin Endocrinol Metab. 2005;90(8):4650-8.

2. Qiao J, Feng HL. Extra-and intra-ovarian factors in polycystic ovary syndrome: impact on oocyte maturation and embryo developmental competence. Human Reproduction Update. 2010 Jul 16;17(1):17-33.

3. Asuncion M, Calvo RM, San Millan JL, Sancho J, Avila S, Morreale HF. A prospective study of the prevalence of the polycystic ovary syndrome in unselected Caucasian women from Spain. J Clin Endocrin Metab. 2000;85(7):2434-38.

4. Knochenhauer ES, Key TJ, Miller M, Waggoner W, Boots LR, Azziz R. Prevalence of the polycystic ovary syndrome in unselected black and white women of the southeastern United States: A prospective study. J Clin Endocrinol Metab. 1998;83(9):3078-82.

5. Kandarakis DE, Kouli CR, Bergiele AT, Filandra FA, Tsianateli TC, Spina GG, et al. A survey of the polycystic ovary syndrome in the Greek island of Lesbos: Hormonal and metabolic profile. J Clin Endocrinol Metab. 1999;84(11):4006-11.

6. Michelmore KF, Balen AH, Dunger DB, Vessey MP. Polycystic ovaries and associated clinical and biochemical features in young women. Clin Endocrinol. 1999;51(6):779-86.

7. Asuncion M, Calvo RM, Millan JL, Sancho J, Avila S, Morreale HF. A prospective study of the prevalence of the polycystic ovary syndrome in unselected Caucasian women from Spain. J Clin Endocrinol Metab. 2000;85(7):2434-8.

8. Azziz R, Woods KS, Reyna R, Key TJ, Knochenhauer ES, Yildiz BO. The prevalence and features of the polycystic ovary syndrome in an unselected population. J Clin Endocrinol Metab. 2004;89(6):2745-9. 
9. Stein IF, Leventhal ML. Amenorrhea associated with bilateral polycystic ovaries. Am J Obst Gynecol. 1935;29:181-91.

10. Rotterdam ESHRE/ASRM-Sponsored PCOS Consensus Workshop Group. Revised 2003 consensus on diagnostic criteria and long-term health risks related to polycystic ovary syndrome. Fertil Steril. 2004;81:1925.

11. Practice committee of American Society of Reproductive Medicine. The evaluation and treatment of androgen excess. Fertil Steril. 2006;86:173-80.

12. Chen X, Yang D, Mo Y, Li L, Chen Y, Huang Y. Prevalence of polycystic ovary syndrome in unselected women from southern China. Eur J Obstet Gynecol Reprod Biol. 2008;139(1):59-64.

13. Li R, Zhang Q, Yang D, Li S, Lu S, Wu X. Prevalence of polycystic ovary syndrome in women in China: A large community based study. Hum Reprod. 2013;28(9):2562-9.

14. Kumarapeli V, Seneviratne RA, Wijeyaratne CN, Yapa RM, Dodampahala SH. A simple screening approach for assessing community prevalence and phenotypes of polycystic ovary syndrome in semiurban population in Srilanka. Am J Epidemiol. 2008;168(3):321-7.

15. Morreale HF, Millan JL. Abdominal adiposity and the polycystic ovary syndrome. Trends Endocrinol Metab. 2007;18(7):266-72.

16. Nidhi R, Padmalatha V, Nagarathna R, Amritanshu R. Prevalence of polycystic ovarian syndrome in Indian adolescents. J Pediatr Adolesc Gynecol. 2011;24(4):223-7.

17. Nair MK, Pappachan P, Balakrishnan S, Leena ML, George B, Russell PS. Menstrual irregularity and poly cystic ovarian syndrome among adolescent girls: A two year follow-up study. Indian J Pediatr. 2012;79(1):6973 .

18. Ferriman D, Gallwey JD. Clinical assessment of body hair growth in women. J Clin Endocrinol Metab. 1961;21(11):1440-7.

19. Keys A, Fidanza F, Karvonen MJ, Kimura N, Taylor HL. Indices of relative weight and obesity. J Chron Dis. 1972;25(6):329-43.

20. Watson PE, Watson ID, Batt RD. Obesity indices. Am J Clin Nutr. 1979;32(4):736-7.

21. WHO. Physical Status: The Use and Interpretation of Anthropometry: Report of a World Health Organization (WHO) Expert Committee. Geneva, Switzerland: World Health Organization. 1995.

22. Balen AH, Laven JS, Tan SL, Dewailly D. Ultrasound assessment of the polycystic ovary: International consensus definitions. Hum Reprod Update. 2003;9(6):505-14.

23. Bharathi R, Swetha S, Neeraja J, Madhavica J, Janani DM, Rekha SN. An epidemiological survey: Effect of predisposing factors for PCOS in Indian urban and rural population. Middle East Fertility Society Journal. 2017;22(4):313-6.

24. Teede HJ, Misso ML, Deeks AA. Assessment and management of polycystic ovary syndrome: summary of an evidence-based guideline. Med J Aust. 2011;195:S65-112.

25. Muralidhara KD, Adhikari PM, Muralidhara DV. Indian Journal of Basic and Applied Medical Research. 2015;4(3):227-36.

26. Spandana JC, Prasanna Kumar Shetty K, Prasanna Kumar Shetty K. A study on the clinical, biochemical and hormonal profile of polycystic ovary syndrome patients attending tertiary care hospital. Int $\mathbf{J}$ Reprod Contracept Obstet Gynecol. 2017;6(5):1986-92.

27. Radha P, Devi RS, Madhavi J. Comparative study of prevalence of polycystic ovarian syndrome in rural and urban population. J Adv Med Dent Scie Res. 2016;4(2):90-5.

28. Hussein B, Alalaf S. Prevalence and characteristics of polycystic ovarian syndrome in a sample of infertile Kurdish women attending IVF infertility center in maternity teaching hospital of Erbil City. Open J Obstet Gynecol. 2013;10(3):577-85.

29. Mandrelle K, Kamath MS, Bondu DJ, Chandy A, Aleyamma T, George K. Prevalence of metabolic syndrome in women with polycystic ovary syndrome attending an infertility clinic in a tertiary care hospital in south India. J Hum Reprod Sci. 2012;5(1):26-31.

30. Clark AM, Thornley B, Tomlinson L, Galletley C, Norman RJ. Weight loss in obese infertile women results in improvement in reproductive outcome for all forms of fertility treatment. Hum Reprod 1998;13(6):1502-5.

31. Atallah D, Al Ruhaily, Maladu UH. Hirsutism in Saudi female of reproductive age, a hospital based study. Ann Saudi. 2008;28(1):28-32.

32. Shanmugham D, Vidhyalakshmi RK, Shivamurthy HM. The effect of baseline serum luteinizing hormone levels on follicular development, ovulation, conception and pregnancy outcome in infertile patients with polycystic ovarian syndrome. Int $\mathrm{J}$ Reprod Contracept Obstet Gynecol. 2018;7:318-22.

33. Teede H, Hutchison S, Zoungas S. The management of insulin resistance in polycystic ovarian syndrome. Trends Endocrinol Metab. 2007;18(7):273-9.

Cite this article as: Sathiya $S$, Renuka S, Famida AM, Britto JJ, Vijayalakshmi K, Sailatha R. Clinical and hormonal profile of patients diagnosed with polycystic ovarian syndrome at tertiary care hospital in Tamil Nadu. Int J Reprod Contracept Obstet Gvnecol 2019:8:3726-31. 